\title{
Adherence characteristics and reasons for abandonment of physical exercise-based interventions in older adults in Latin America: A scoping review \\ Características de la adherencia y motivos del abandono de las intervenciones basadas en el ejercicio físico en adultos mayores en América Latina: una revisión de alcance
}

*Igor Cigarroa, **Rafael Zapata-Lamana, *Gonzalo Leiva-Gajardo, ***EduardoVásquez, ****Eva Parrado-Romero, *****Jaime Vásquez-Gómez, ******Cristian Álvarez, *******, ********Fanny Petermann-Rocha, **Daniel Reyes-Molina

*Universidad SantoTomás (Chile), **Universidad de Concepción (Chile), ***Servicio Especializado en Psiquiatría yAdicciones (Chile), ****Universidad Autónoma de Barcelona (España), *****Universidad Católica del Maule (Chile), *******Universidad de Los Lagos (Chile), *******University of Glasgow (Reino Unido), ********Universidad Diego Portales (Chile)

\begin{abstract}
This review describes the adherence characteristics and reasons for abandonment physical exercise-based interventions in older adults in Latin America.This scoping review was conducted in accordance with the PRISMA statement. Articles were searched in MEDLINE by PubMed, ELSEVIER by SCOPUS and SciELO.The MeSH terms «Exercise», ExerciseTherapy» and «Aged» were used between 2015 and 2020. We searched for articles in Spanish, English, and Portuguese carried out in people aged 65 years and over. 101 out of 4,642 randomized controlled trials (RCT) were included.A total sample of 5,013 older adults (79\% women), with an average age of 68.2 years started their studies and 4,312 finished it, presenting an adherence to the interventions of $86 \%$. Most of the studies were carried out in healthy older adults, in places enabled for the practice of physical activity, in charge of a physical activity professional, and the interventions were performed carried out through group therapeutic exercise. No article reported information on the minimum time of participation to the session to be considered as carried out. Only $30 \%$ of the articles reported the minimum participation of older adults in the intervention to include them in the study analysis, and $21 \%$ reported the average number of sessions attended to the intervention. The main reasons for abandonment were personal causes unrelated to the intervention. Only $5 \%$ of the articles reported injury of one of the participants (in two of them the injury was related to the intervention applied). This review characterized the physical exercise programs in older adults in Latin America, as well the adherence characteristics and the main reasons for abandonment to physical exercise-based interventions, by summarizing available evidence derived from RCTs.
\end{abstract}

Keywords: Aged; Exercise;TreatmentAdherence and Compliance; LatinAmerica; Scoping Review.

Resumen. Esta revisión describe las características de adherencia y motivos de abandono de las intervenciones basadas en ejercicio físico en adultos mayores enAmérica Latina. Esta revisión de alcance se realizó de acuerdo con la declaración PRISMA. Los artículos fueron buscados en MEDLINE por PubMed, ELSEVIER por SCOPUS y SciELO. Los términos MeSH «Ejercicio», Terapia de ejercicio «y» Anciano «se utilizaron entre 2015 y 2020. Se buscaron artículos en español, inglés y portugués realizados en personas de 65 años o más. Se incluyeron 101 de 4.642 ensayos aleatorizados controlados (ECA), en una muestra total de 5.013 adultos mayores (79\% mujeres), con una edad promedio de 68,2 años, que iniciaron sus estudios finalizando 4.312, presentando una adherencia a las intervenciones del 86\%. La mayoría de los estudios fueron realizado en adultos mayores sanos, en lugares habilitados para la práctica de actividad física, a cargo de un profesional de actividad física, y las intervenciones se realizaron a través de ejercicio terapéutico grupal. Ningún artículo reportó información sobre el tiempo mínimo de participación a la sesión Sólo el 30\% de los artículos informaron la participación mínima de los adultos mayores en la intervención para incluirlos en el análisis del estudio, y el 21\% informó el número medio de sesiones. atendidos a la intervención. Los principales motivos de abandono fueron causas personales ajenas a la intervención. Solo el 5\% de los artículos reportaron lesión de uno de los participantes (en dos de ellos la lesión estuvo relacionada con la intervención aplicada). Esta revisión caracterizó los programas de ejercicio físico en adultos mayores en América Latina, así como las características de adherencia y los principales motivos de abandono a las intervenciones basadas en ejercicio físico, al resumir la evidencia disponible derivada de ECA.

Palabras Clave:Envejecido; Ejercicio;Adherencia y Cumplimiento delTratamiento;América Latina; Revisión de alcance.

\section{Introduction}

Nowadays, all countries are experiencing an increase in the prevalence of older adults (OA) (United Nation, 2019a). In 2019 the number of people aged 65 years and older was 703 million worldwide; however, this is projected to rise to 1.5 billion by 2050 (i.e., from $9 \%$ to $16 \%$ ) (United Nation, 2019a, 2019b). Latin America is not exempted from this phenomenon. In fact, for this same period, it is estimated an increase from 56.4 to

Fecha recepción: 06-05-21. Fecha de aceptación: 03-10-21

Daniel Reyes-Molina

danielreyes@udec.cl
144.6 million, leading to an increase of $156 \%$ of $\mathrm{OA}$ in the region (United Nation, 2019b). Aging is a heterogeneous process related to the health condition of each individual. Thus, significant differences in health status and functional capacity have been described in people with the same chronological age (Mitnitski et al., 2002). This phenomenon is known as pathological aging. On the other hand, half of the world's deaths are attributed to diseases associated with aging (Costantino et al., 2016; Huang et al., 2010).

Physical inactivity (PI) in the older population (i.e. less than 150 minutes of moderate-intensity aerobic physical activity or less than 75 minutes of physical 
activity vigorous-intensity aerobics per week) has been recognized as one of the main causes of physical, cognitive and functional impairment in this population (WHO, 2020). Additionally, PI it is one of the most common causes of the heart disease, type 2 diabetes, chronic obstructive pulmonary disease, stroke, frailty syndrome, sarcopenia, Alzheimer's disease, cancer, chronic kidney disease and depression (McPhee et al., 2016). Although multiple studies have reported physical exercise (PE) in OA with varied results, the majority has concluded that PE decreases with aging (Sun et al., 2013). Therefore, it is proposed that PE practice on a regular basis reduces the mortality rate from all causes, disability, cardiovascular disease, and cognitive and functional impairment in OA (Mora \& Valencia, 2018). Among the benefits of the regular practice of PE through different programs, studies have reported a lower risk of falls, improves balance and function (Hill et al., 2015), increases strength and maximum oxygen consumption (Fleg, 2012), improves and prevents sarcopenia (Landi et al., 2014). PE has also been associated with benefits in the psychosocial and cognitive aspect in this population, reducing symptoms of depression (Araque-Martínez et al., 2020; da Silva et al., 2019), preventing cognitive deterioration (Romero Ramos et al., 2020; Van Gelder et al., 2004), and increasing quality of life (Galloza et al., 2017).

Based on the above, it is proposed that all OA should perform PE to obtain the benefits that this entails - unless there are contraindications to do so. In Latin American countries, public health and PE institutions guide the community regarding $\mathrm{PE}$ realization to improve endurance, strength, balance, flexibility and quality of life in OA (ACEMI, 2011; Dirección de Promoción de la Salud y Control de Enfermedades No Transmisibles, 2013; Gobierno de Chile, 2017; Ministerio de Salud Pública del Ecuador, 2011; Secretaria Nacional de Deporte, 2018), proposing as alternative activities the ones in the aquatic environment (Secretaria Nacional de Deporte, 2018). Several studies have also been conducting programs using multi-component $\mathrm{PE}$, where aerobic capacity, flexibility, balance, strength, and cognitive performances were increased, decreasing on the other hand symptoms of depression or anxiety (Bueno et al., 2018; Carvalho et al., 2009; Gonçalves et al., 2019; Nacional Costa Rica et al., 2018; Rico-Gallegos et al., 2020; Salinas et al., 2005).

However, to obtain the known benefits of PE, a continues participation in intervention programs is required. This is when we must understand the term «adherence», which can be understood as maintaining a regimen or exercise program for an extended period after an initial phase of adaptation has been completed (Lox et al., 2014). However, OA have a higher burden of comorbidities, lower social support, and higher disability and depression rates. These factors have been associated with lower adherence to exercise in people with specific health conditions (Picorelli et al., 2014). Other factors that have also been described as limiting the participation in PE-based interventions in this population are related to lack of time and motivation, boredom, fear of falling, and environmental factors such as accessibility, cost, and safety (Valenzuela et al., 2018).

Although there is recent evidence global focused on adherence to PE-based interventions, this evidence focused only on particular health conditions or programs of certain characteristics (Di Lorito et al., 2020; Hong et al., 2008; Medina-Mirapeix et al., 2009; Nicolson et al., 2017; Valenzuela et al., 2018). Currently, there is no review of the literature that reveals the available evidence on adherence and reasons for the abandonment of PE-based interventions for OA in Latin American. Therefore, this review aimed to describe the adherence characteristics and reasons for abandonment to PE-based interventions in OA in Latin America.

\section{Survey methodology}

The scoping review was carried out under the guidelines established by PRISMA declaration (Liberati et al., 2009). The PRISMA checklist can be found in the supplementary article files (Appendix 1). The manuscript was not registered in PROSPERO. PROSPERO does not currently accept registrations for scoping reviews, literature reviews or mapping reviews.

\section{Search strategy for identifying articles}

The following databases were reviewed and presented in the following order: MEDLINE by PubMed, ELSEVIER by SCOPUS and SciELO. The search covered the period from 2015 to 2020 . For the development of the research, the MeSH terms were used: «Exercise», Exercise Therapy» and «Aged». The search strategy followed the guideline of Peer Review of Electronic Search Strategies (PRESS) (McGowan et al., 2016).

The general search syntax was: («Exercise» OR «Exercise Therapy») AND («Aged») and was adapted to each database by applying the following filters: a) PubMed: Type of article: randomized controlled essay, 
Publication date: five years, Languages: English, Spanish and Portuguese, Age: aged:65+ years and 80 and over. b) Scopus: Exclusion: Medline, Year of publication: 2015 to 2020, Publication status: final, Document type: article, Country: Latin American countries, Languages: English, Spanish and Portuguese, Keywords: words related to the subject under study. c) SciELO: Country: Brazil, Colombia and Chile, Year of publication: 2015 to 2020, Literature type: article.

Search strings for all databases is shown in the supplementary material (Appendix 2).

\section{Study selection}

The inclusion criteria were as follow: I) Intervention; Ia) Type of intervention: Endurance, strength, multicomponent, concurrent, multidomain, HIIT or neuromotor, or other related to physical activity or exercise, Ib) Distinctive intervention: Must be the only intervention to use based on physical activity or exercise (no other interventions), Ic) Period of time: last at least for four weeks. II) Age: men and women 60 years and older who are community-dwelling older adults, living in long-term care, residential homes, or have been hospitalized with different health status. III) Type of article: Randomized controlled clinical trial, IV) Country of origin: Only Latin-American countries, V) Languages: English, Spanish and Portuguese. Revisions, editorial documents, protocols, or thesis were excluded.

\section{Data extraction}

In the first step, duplicate articles were removed from databases using Mendeley. According to the inclusion and exclusion criteria, all titles and abstracts were screened for suitability by two reviewers (G. L-G and I.C). In the next step, articles that met the inclusion criteria were selected, and, when decisions could not be taken using only the title and abstract of the article, the full-text was retrieved. The included articles were independently verified by the two reviewers (G. L-G and I.C); however. A consensus was achieved when there was a disagreement. The flowchart proposed by the PRISMA was used to show the search for articles (Figure 1). A standardized questionnaire was applied by the reviewers to extract the data from the included articles, in order to synthesize the evidence.

\section{Risk of bias assessment tool}

The Cochrane Tool «The Cochrane Manual of Systematic Reviews of interventions» (Sterne et al., 2019) was used to assess risk of bias. This tool allowed an assessment of the methodological validity of the 101 articles included in this review (Figure 2). The instrument consists in six items that evaluate: a) selection bias, b) completion bias, c) detection bias, d) wear bias and e) notification bias and f) other biases. However, for this review, the item «other Biases» was not considered due to characteristics of the interventions analyzed. Each article was scored independently by two reviewers (G. L-G and I.C), and scores were compared. When there was a disagreement, a consensus was achieved. A detailed description of the analysis is presented in the results section, along with a graphic representation. The risk of bias was measured using three categories: low risk (green color), unclear risk (yellow color), high risk (red color) according of weighted bar plot of the distribution of risk-of-bias judgements within each bias domain of Cochrane tool (Sterne et al., 2019).

\section{Strategy for narrative synthesis}

A summary of the articles' main findings included, related to adherence and grounds for abandonment of $\mathrm{OA}$ in PE-based interventions in Latin America, was provided. The main information is presented in figures and summary tables. The information extracted included: (a) general characteristics of articles and OA (Table 1); (b) Characteristics of PE-based intervention associated with adherence (Table 2); (c) reasons for the abandonment of PE-based interventions (Table 3); (d) characteristics of PE-based intervention associated with adherence and reasons for abandonment (Table 4) ;(e) Profile of PE-based intervention with adherence of 100\% and less than 70\% (Table 5).

\section{Results}

\section{Literature research}

Figure 1 shows the flowchart proposed by the PRISMA Declaration. A total of 4,642 potential articles on

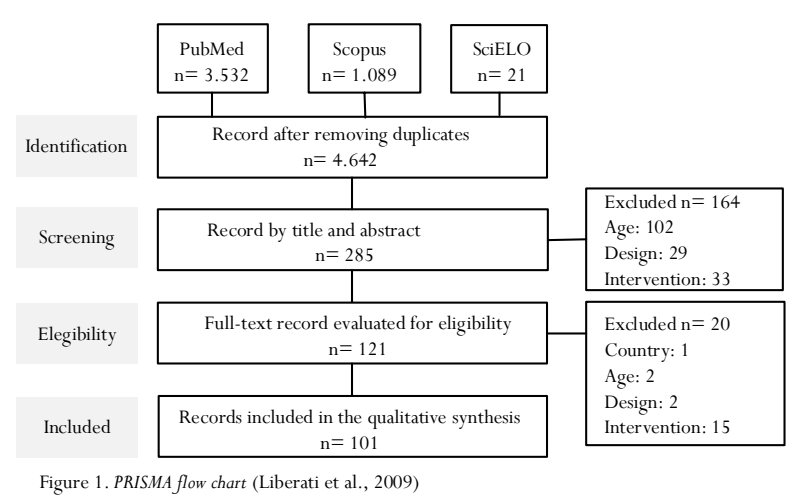


physical activity and physical exercise were identified in OA from Latin American. Following the exclusion of duplicates in the databases, the screening and eligibility criteria were applied. 101 articles were finally included for the narrative synthesis in this review (Figure 1).

\section{Risk of bias assessment}

Regarding the analysis by type of bias, it can be seen that the distribution of biases classified as low risk or unclear risk was similar, except for the performance bias that presented an $86 \%$ unclear risk, and the reporting bias, which presented $100 \%$ low risk. Only three types of components had high-risk of bias (selection, performance and detection), although for all cases, it was less than 10\% (Figure 2).

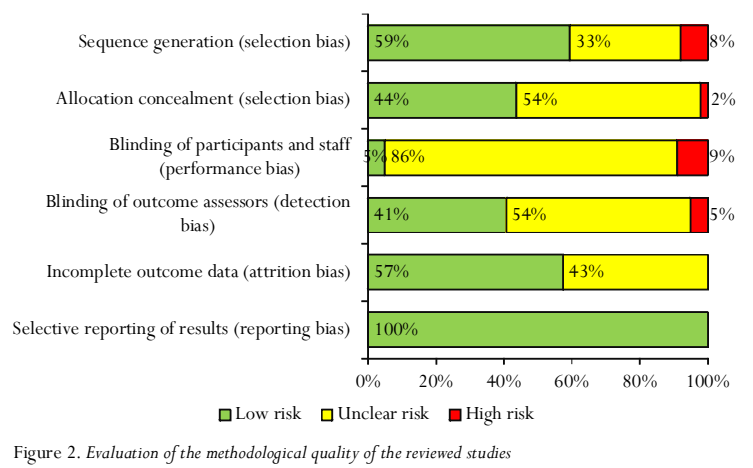

General characteristics of the articles and Older Adults (OA)

A total of 101 articles were included in this scoping review corresponding to 5,013 individuals (79\% women) with an average age of 68.2 years (age ranged from 63.6 to 84.8). A total of 91 studies were conducted in Brazil, five in Chile, two in Colombia, two in Mexico and one in Ecuador. Regarding the distribution of the age range of the selected OA, $97 \%$ of the articles included OA from 60 years or more, of these $70.83 \%$ included OA between 71 and 80 years, and 16\% included OA older than 80 years. A total of $72 \%$ of the studies were conducted in OA without underlying pathology as the objective of the study, while $28 \%$ of the articles reported having performed intervention on OA with a particular health status. Among this health status, non-communicable diseases (NCDs) were those reported in the majority of the studies $(53,6 \%)$, followed by neurodegenerative diseases $(32.1 \%)$, musculoskeletal diseases, and cancer $(10.7 \%$ and $0.6 \% \%$, respectively) (Table 1 ).

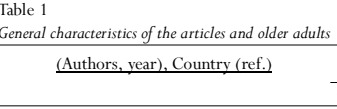

(de Queiroz et al., 2016), Brazil (37) (Antunes et al., 2015), Brazil (38) (R. T. De Oliveira et al., 2017), Brazil (40) (L. C. de Oliveira et al., 2016), Brazil (41) (Mazini Filho et al., 2017), Brazil (42) (Teodoro et al., 2019), Brazil (43) (G. O. R. Santos et al., 2019), Brazil (44) (Dueñas et al., 2019), Colombia (45) (Dirauá et al., 2019), Brazil (46)
(Pran at a (Piraua et al., 2019), Brazil (46)
(Arantes et al., 2015), Brazil (47) (L. G. Lima et al., 2015), Brazil (48) (D. . . De Oliveira et al., 2019), Brazil (49) (D.V. De Oliveira et al., 2019), Brazil
(Langoni et al., 2019), Brazil (50)
(Nascimento et al., 2019), Brazil (51) (Nascimento et al., 2019), Brazil (51) (Dantas et al., 2016), Brazil (52) (Leandro et al., 2019), Brazil (53) (Tiggemann et al., 2016), Brazil (55) (R. G. da Silva et al., 2017), Brazil (56) (Taglietti et al., 2018), Brazil (57) (Taglietti et al., 2018), Brazil (57) (C. B. Ferreira et al., 2018), Brazil (59) (López et al., 2015), Chile (60) (Lopez et al., 2015), Chile (60)
(Suzuki et al., 2018), Brazil (61) (Ortiz-ortiz et al., 2019), Mexico (62) Guedes et al., 2016), Brazil (63) (Agner et al., 2018), Brazil (64)
(Rodrigues-Krause et al., 2018), Brazil (65) (Rodrigues-Krause et al., 2018),
(Ferrari et al., 2016), Brazil (66) (Ferrari et al., 2016), Brazil (66) (Namirez-Campillo et al., 2016), (Neto et al., 2018), Brazil (68)
(Cavalcante et al., 2018), Brazil (69) (Dias et al., 2015), Brazil (70) (Henrique et al., 2019), Brazil (71)
(Ramírez-Villada et al., 2019), Colombia (72) (Ramírez-Villada et al., 2019), Colombia (72) (Neta et al., 2016), Brazil (74) (Bacha et al., 2018), Brazil (75) (L. Dos Santos et al., 2018), Brazil (76) (Gomeñuka et al., 2019), Brazil (77) (Campos De Oliveira et al., 2015), Brazil (78) (Gomes et al., 2018), Brazil (79) (Santiago et al., 2018), Brazil (80) (Botton et al., 2018), Brazil (81) (Gadelha et al., 2016), Brazil (82) (Barbosa Rezende et al., 2015), Brazil (83) (Martins et al., 2015), Brazil (84) (Herminia Gallo et al, , 2015), Brazil (85) (Ruaro et al., 2019), Brazil (86) (C. M. da S. e. Silva et al., 2018), Brazil (87) (Miranda-Aguilar et al., 2019), Chile (88) (Cadore et al., 2018), Brazil (89) (De Resende Neto et al., 2016), Brazil (90) (I. G. Silva et al., 2018), Brazil (91)

(M. A. R. Da Silva et al., 2019), Brazil (92) (Ramirez-Campillo et al., 2018), Chile (93) (Brandão et al., 2018), Brazil (94) Hall López et al., 2017), Mexico (95) (Medeiros et al., 2018), Brazil (96) Vargas \& Rosas, 2019), Ecuador (97) Scarabottolo et al., 2017), Brazil (98) Damorim et al., 2017), Brazil (99) (Louza et al., 2019), Brazil (101) (G. D. Santos et al., 2015), Brazil (102) (Moreira et al, 2018), Brazil (103) (Martinez et al., 2018), Chile (104) (Santana et al., 2016), Brail (105) (Santana et al., 2016), Brazil (105) (Coelho-Júnior et al., 2019), Brazil (107) (Pestana et al., 2016), Brazil (108) (Gestana et al., 2016), Brazil (108) (Gambassi et al., 2015), Brazil (109) (Ribeiro al., 2015), Banl (1110) (Ribeiro et al., 2015), Brazil (111) Cunha et al., 2019), Brazil (112) (T. A. de Lima et al., 2019), Brazil (114) (T., A. de Lima et al,, 2019), Brazl (114) (Olivio a (Oliveria-Dantas et al., 2020), Brazil (116)

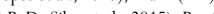
(P. B. Da Silva te al., 2015), Brazil (118 (Alves et al., 2019), Brazil (119) (R. M. Ferreira et al., 2018), Brazil (120) (Rosa et al., 2017), Brazil (121) (Rodacki et al., 2017), Brazil (122)
(Aragão-Santos et al., 2019), Brazil (123) (Aragào-Santos et al., 2019), Brazil (23) (Ferraz et al., 2018), Brazil (124) (Moreira Antunes et al., 2015), Brazil (126) (I. F. De Carvalho et al., 2018), Brazil (127) (Barbalho et al., 2017), Brazil (128) (de Oliveira Silva et al., 2019), Brazil (129) (Lixandrão et al., 2016), Brazil (130) (Ribeiro et al., 2016), Brazil (131) Da Silveira Fontenele De Meneses et al.,

2019), Brazil (132)
(Monteiro-Junior et al., 2017), Brazil (133) (Aveiro et al., 2017), Brazil (134) (M. R. Silva et al., 2018), Brazil (135) (V. H. De Oliveira et al., 2019), Brazil (136) (Simao et al., 2019), Brazil (137) Health Status: ND, Neurodegenerative Disease; Symbology: ï, stated variable; - , non-stated variable.

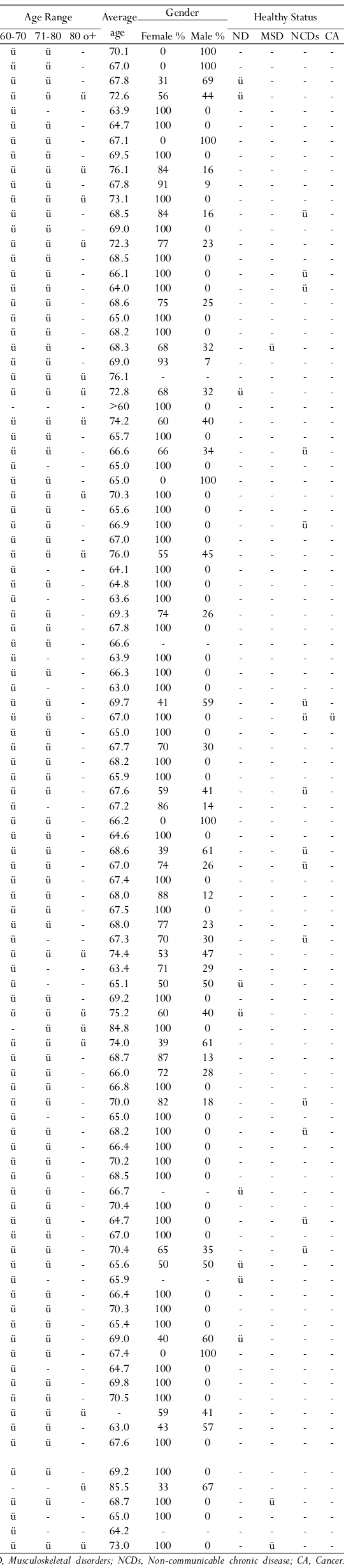


Characteristics of PE-based interventions associated with adherence

A total of $67 \%$ of the articles reported the exclusion criteria used to delimit the sample, 5,013 older adults started their studies and 4,312 finished it, presenting an adherence to the interventions of $86 \%$. A total of $88 \%$ of the article $(n=90)$ had complete adherence to the interventions equal to or greater than $70 \%$. Of these, only $40 \%$ of the articles $(n=36)$ reported complete adherence to the intervention (100\%). No article reported information on the minimum time of participation to the session to be considered completely. On the other hand, $30 \%(\mathrm{n}=30)$ of the articles reported the minimum requirements for participation in the interventions, to be considered in their analyzes. In this sense, on average the minimum percentage of participation required by the studies was $77 \%$. This percentage was lower compared to the effective percentage of attendance to the interventions (87\%). However, this information was declared only in $21 \%$ of the articles $(\mathrm{n}=21)$ (Table 2).

\section{Reasons of OA for abandonments during the PE-based interventions}

A total of $66 \%$ of the articles reported the abandonment one or more OA during the PEbased intervention. On average, $13 \%$ of OA that initiated the intervention left for different causes. The main causes include lack of time, moving to another city, and lack of motivation (336 OA). Health reasons were indicated as reasons for abandonment in 35\% of the articles (140 OA), followed by attendance (181 OA). Additionally, two studies reported decease of participants during the intervention period, none related to the intervention while five studies reported injury of one of the participants (in two of them, the injury was related to the intervention applied) (Table 3).

\section{Characteristics of PE-based intervention associated with adherence and reasons of abandonment}

Only 36 studies reported where the intervention took place and categorized into places enabled or not enabled for PE practice. A total of $88.6 \%$ of these articles $(n=31)$ involved
Table 2

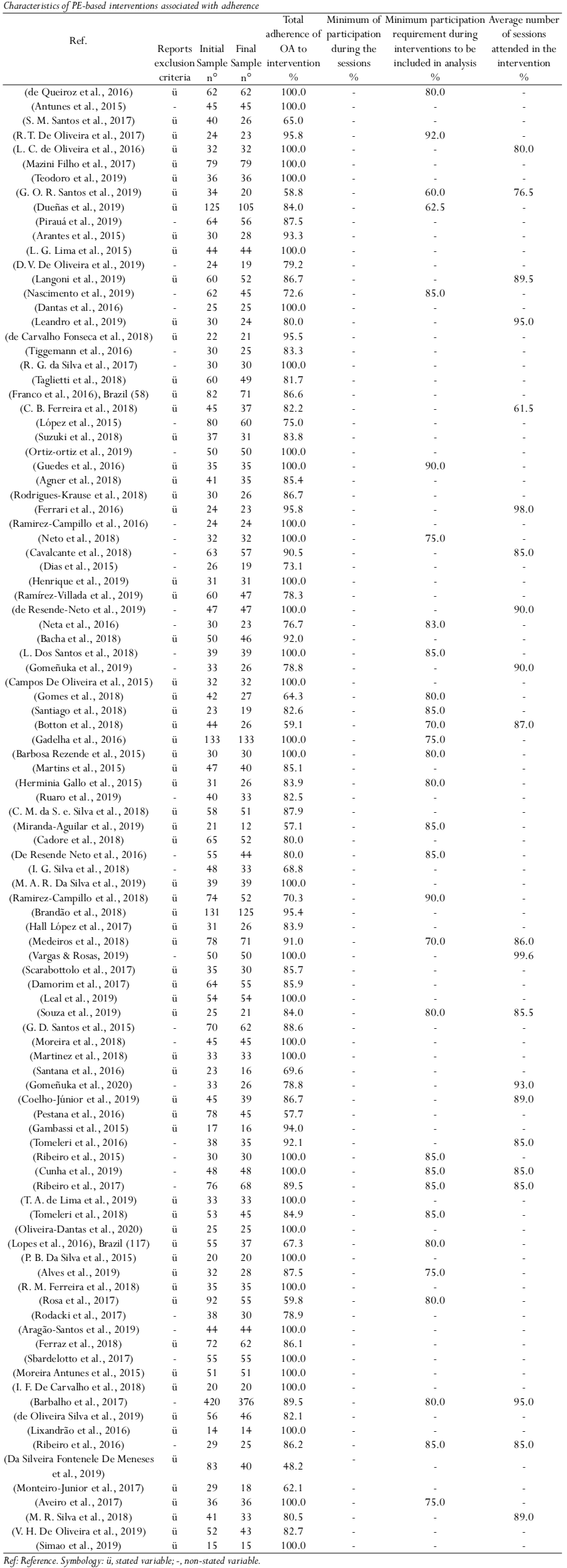




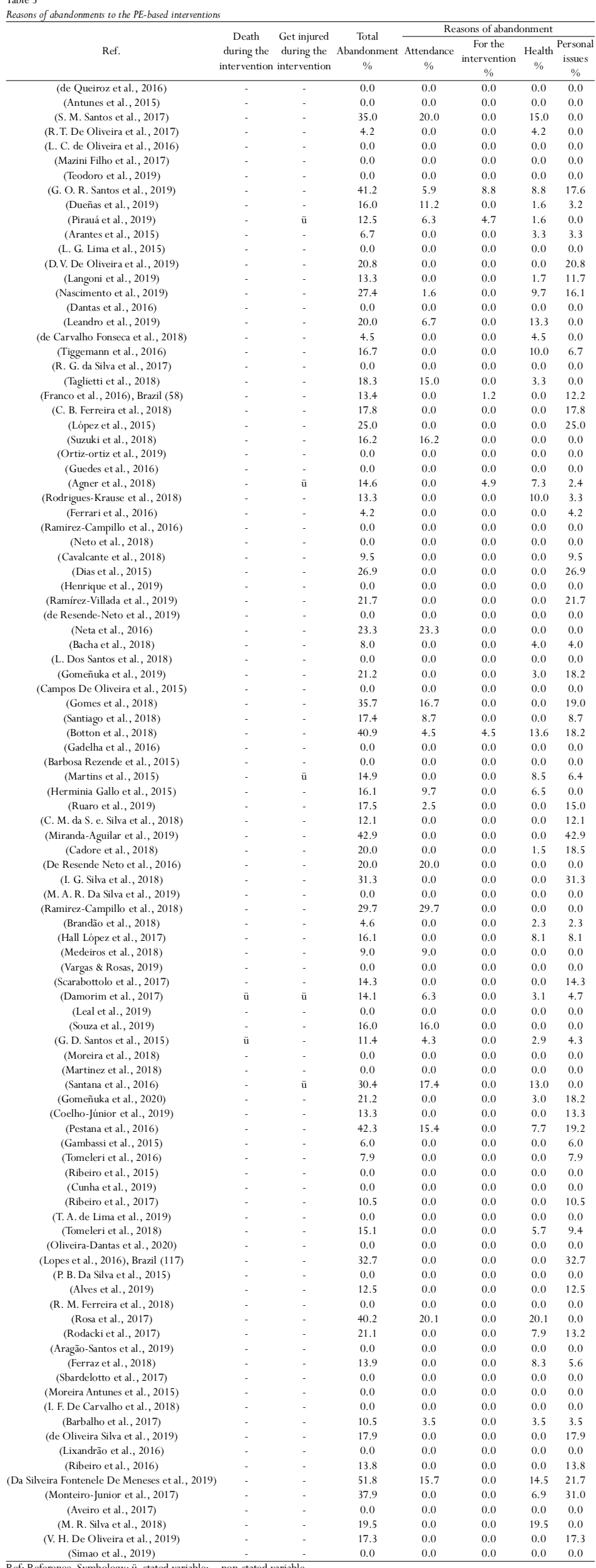

in enabled locations (16.1\% sports centers, $22.6 \%$ health centers and $61.3 \%$ in laboratories or universities), while $13.4 \%(n=5)$ were carried out in non-enabled locations (20\% at home and $80 \%$ of interventions at elderly's residence centers). Forty-nine articles reported the intervention format of which $36,7 \%(n=19)$ used an individual intervention format, while $63,2 \%(n=31)$ used a group intervention format. As for the intervention type used, $62 \%$ of the articles performed the intervention through physical exercises (PE), $25 \%$ performed the intervention based on therapeutic exercise (TE) and 13\% in recreational activities (RA). Sixty-six articles reported the professional in charge. Of these articles, $53 \%$ of the interventions were led by physical activity professionals $(\mathrm{n}=52)$ and, $13 \%$ by health professionals ( $\mathrm{n}=14$ articles).

On the other hand, the intervention length was $>1$ to 3 months in 69 articles, while in the remaining 31\% was longer than three months. Regarding the intervention frequency (i.e. total scheduled sessions per week), $50 \%$ of articles reported having performed interventions e» 3 or more times per week, $43 \%$ of $d » 2$ or fewer times per week, and $7 \%$ reported having changed the frequency from two to three times per week throughout the intervention. A total of $71 \%$ of the articles reported the session length (i.e. session duration in minutes). Of these articles, 38.9\% reported 60-minute interventions $(n=28)$, $36.1 \%$ reported interventions lasting between 40 and 50 minutes $(n=26), 18.3 \%$ made interventions lasting less than 40 minutes $(n=13)$, and only $6.7 \%$ made interventions lasting more than an hour $(\mathrm{n}=5)$ (Table 4).

\section{Profile of PE-based interventions with} adherence of $100 \%$ and less than $70 \%$

About $36 \%$ of the articles had a $100 \%$ adherence to the intervention, while $11 \%$ had an adherence $<70 \%$. For both adherence conditions, OA's predominant characteristics were similar; between 60 and 70 years, female and without the presence of underlying pathology during the intervention period. As per the characteristics of the intervention, it was evident in both interventions that the 


\section{Discussion}

(Rodrigues-Krause et al., 2018)

(Ferrari et al., 2016)

(Ramirez-Campillo et al., 2016)

(Neto et al., 2018)

(Davalcante et al., 2018)
(Dias et al., 2015)

(Dias et al., 2015)

(Henrique et al., 2019)
(Ramírez-Villada et al., 2019)

(de Resende-Neto et al., 2019)

(Neta et al., 2016)

(Bacha et al., 2018)

(L. Dos Santos et al., 2018

(Campos De Oliveira et al., 2015)

(Gomes et al., 2018)

(Santiago et al., 2018)

(Botton et al., 2018)

(Gadelha et al., 2016)

(Martins et al., 2015)
(B)

erminia Gallo et al., 2015)

(Ruaro et al., 2019)

(C. M. da S. e. Silva et al., 2018)

Miranda-Aguilar et al., 2019)

(Cadore et al., 2018)

(De Resende Neto et al., 2016)

(I. G. Silva et al., 2018)

(M. A. R. Da Silva et al., 2019)

(Ramirez-Campillo et al., 2018)

(Brandão et al., 2018)

(Hall López et al., 2017)

(Medeiros et al., 2018)

(Vargas \& Rosas, 2019)
(Scarabottolo et al., 2017)

(Damorim et al., 2017)
(Leal et al., 2019)

(Souza et al., 2019)

(G. D. Santos et al., 2015)

(Moreira et al., 2018)

(Martinez et al., 2018

(Santana et al., 2016)

(Gomeñuka et al., 2020)

(Coelho-Júnior et al., 2019)

(Pestana et al., 2016)

(Gambassi et al., 2015)

(Tomeleri et al., 2016)

(Ribeiro et al., 2015)

(Cunha et al., 2019)

(Ribeiro et al., 2017)

(T.A. de Lima et al., 2019)

(Tomeleriet al., 2018)

(Oliveira-Dantas et al., 2020)

(Lopes et al., 2016), Brazil (117)

(P. B. Da Silva et al., 2015)

(Alves et al., 2019)

R. M. Ferreira et al., 2018)

(Rosa et al., 2017)

(Rodacki et al., 2017)

Aragão-Santos et al., 2019)

(Ferraz et al., 2018)

(Sbardelotto et al., 2017)

Moreira Antunes et al., 2015)

I. F. De Carvalho et al., 2018

(Barbalho et al., 2017)

(de Oliveira Silva et al., 2019)

(Lixandrão et al., 2016)

(Ribeiro et al., 2016)

(Da Silveira Fontenele De Meneses et al., 2019)

(Monteiro-Junior et al., 2017)

(Aveiro et al., 2017)

(M. R. Silva et al,, 2018)

H. De Oliveira et al., 2019) 

increase the risk of both adverse events and biased results (Patino \& Ferreira, 2018). The average adherence to $\mathrm{PE}$

What was already known and contrasted with the findings of this review?

Regarding the general characteristics of the articles, it should be noted that they were developed in only five countries in Latin America, where 91\% correspond to Brazil, which could be associated with the fact that it is the country that develops the most research in the region (Grupo Banco Mundial, 2019). Only 16\% of the interventions included OA over 80 years old, a fact that attracts attention as it is known that the PE brings both physical and psychosocial benefits in OA no matter the age of subjects (Mora \& Valencia, 2018; Van Gelder et al., 2004). This could be because as age progresses, the health condition changes and the presence of chronic diseases increases in OA (Peranovich, 2016), which could lead to an increased risk of unwanted side effects associated with PE practice, although these should be minimized by adapting interventions individually to the needs and characteristics of participating subjects (Van Gelder et al., 2004). In terms of sex distribution of each intervention, studies included more women (79\%) than men. Regarding OA's health condition recruited for interventions, the highest prevalence was a $15 \%$ of chronic NCDs, followed by neurodegenerative diseases, which is consistent with the phenomenon of progressive ageing population (Peranovich, 2016). In terms of remaining conditions, only 3\% and 1\% developed OA interventions with musculoskeletal diseases and cancer, respectively. This could be due to some key factors common in subjects with these conditions, such as physical discomfort and fatigue, among others (Buffart et al., 2014). Other reviews have also managed to identify very few studies in these particular health conditions in OA (Forbes et al., 2020; Nicolson et al., 2017), which draws attention due to the high prevalence of these diseases today.

A total of $67 \%$ of the articles report exclusion criteria. This is consistent with previous reviews that demonstrated exclusion criteria defined in 69 out of 101 selected articles (Porzsolt et al., 2019). The importance of correctly defining exclusion criteria in clinical trials lies in integrating characteristics of subjects prone to lose during intervention or follow-up for various intervention was $87 \%$, using as a measurement method the percentage of subjects who completed the intervention, values identical to previous studies (Hong et al., 2008). However, other studies have highlighted the varied methodology used to measure adherence to interventions (Findorff et al., 2009; Picorelli et al., 2014), including the percentage of subjects who completed the intervention, the percentage of attendance at available sessions and the average number of attendance sessions per week. Concerning session adherence, no article in this review reported adherence to the session, which is in agreement with previous systematic reviews where this factor is not considered (Hong et al., 2008; Picorelli et al., 2014). Besides, only $21 \%$ of the articles detailed the average percentage of sessions attended, which averaged $87 \%$, which is consistent with averages obtained in previous reviews (Hong et al., 2008; Picorelli et al., 2014). On the other hand, only $30 \%$ of articles reported the minimum percentage required to be included in the data analysis, information of great value to know the effective participation of $\mathrm{OA}$, which should be recorded in future interventions.

A low percentage of $\mathrm{OA}$ deaths was observed during the intervention. None related to exercise programs and a low percentage of injured OA was detected, which could indicate that the PE-base interventions in Latin America interventions are safe, reliable and potentially replicable (Peranovich, 2016). The reason for abandonment corresponding to personal causes was reported in $49 \%$ of the articles, where they were considered in the same line as previous studies, aspects such as lack of time, traveling problems or lack of motivation (Hancox et al., 2019; Picorelli et al., 2014) as well as health reasons (cause reported in $35 \%$ of the articles), but which, as it has highlighted, not derived from the intervention applied. For attendance, 25\% of the articles reported excluding OA for this reason and, finally, only $5 \%$ of the articles reported OA exclusion whose abandonment was motivated by the intervention. While elimination by attendance is not considered a barrier to adherence to the PE-based interventions, it would be logical to infer that the non-attendance could 
be due to reasons not informed by the $\mathrm{OA}$ and related to both personal characteristics and sociodemographic factors presented in their environment (Findorff et al., 2009).

Although some studies have shown good results in terms of adherence and impact of $\mathrm{OA}$ interventions carried out both at home and in residential centers (Faber et al., 2006; Hill et al., 2015), it was not possible to establish relationships between the place of intervention and $\mathrm{OA}$ adherence due to a large number of articles that did not report this information, coupled with the fact that only one article used an PE-based intervention performed at the home of the OA. As for the intervention format, the preference for using group interventions may be given by the social support that could occur between OA, which is an important factor in promoting adherence to the PE-based interventions in this population (Fraser \& Spink, 2002), in addition to the reduced use of time and resources of this format compared to individual interventions. Finally, concerning the type of intervention used, $63 \%$ of the articles used structured PE-based interventions, which is characterized by being a planned and structured activity, to improve or maintain physical fitness or any of its components (WHO, 2020), 25\% of the articles used interventions based on therapeutic exercise, which is characterized by being used to recover function in subjects with certain health conditions (Taylor et al., 2007). Only $13 \%$ of the articles made interventions through recreational activities, which could be based on researchers' interest in knowing the effects of structured and therapeutic PE on elderly, controlling the different variables that could affect the results obtained with the interventions.

The interventions' design-mainly group session in those who reported a $100 \%$ adherence versus individual session in those with $70 \%$ - might explain the adherence difference. Apparently doing physical activity in other OA companies and receiving their support and companionship would be an important factor in increasing adherence (Fraser \& Spink, 2002).

\section{What are the contributions and scope of this review?}

This scoping review provides a broad and updated view of the characteristics of PE-based interventions that are being developed in Latin America, which made it possible to generate a profile of the OA that most benefit from PE programs, the characteristics of adherence and most frequent reasons for abandoning these interventions. In addition, this review allowed us to know the existing gaps in relation to the attendance record and reasons for abandoning the OA to PE-base interventions, being able to encourage the development of future studies in this area, as well as their inclusion as relevant factors when designing and prescribing PE-base intervention for this population.

\section{Strengths and limitations}

The work was conducted according to the PRISMA guidelines and it was not limited to one language only; therefore, the language bias risk was minimal. We found that the search was restricted to the last five years to find the latest and updated available evidence among the limitations. We are aware that there may be highquality evidence in previous years that was not included. Furthermore, this scoping review lacked meta-analysis due to the studies' heterogeneity, so there is only a qualitative analysis of the phenomenon studied.

\section{Conclusions}

Total adherence to interventions was $87 \%$. No article reported information on the minimum time of participation to the session to be considered as done. Only 30\% of the articles reported the minimum participation of the $\mathrm{OA}$ in the intervention to include them in the study analysis and $21 \%$ reported the average session attendance to the intervention. The main reasons for abandonment were personal causes unrelated to the intervention. A low percentage of OA deaths was observed during the intervention, none related to exercise programs and only $5 \%$ of the articles reported injury of one of the participants (in two of them the injury was related to the intervention applied). Most of the PE-based interventions were developed in spaces set up for the practice of PE, in charge of a physical activity professional, in a group modality and using therapeutic exercise as a base intervention. The most frequently used parameters for PE-based interventions included intervention length of three or fewer months, with an intervention frequency of three or fewer times a week, and a session length of 60 minutes.

\section{References}

ACEMI. (2011). Sé activo fisicamente y siéntete bien. https: / / www.minsalud.gov.co/sites/rid/Lists/BibliotecaDigital/ $\mathrm{RIDE} / \mathrm{VS} / \mathrm{PP} / \mathrm{ENT} /$ se-activo-fisicamente-sientetebien.pdf 
Agner,V. F. C., Garcia, M. C., Taffarel,A.A., Mourão, C. B., da Silva, I. P., da Silva, S. P., Peccin, M. S., \& Lombardi, I. (2018). Effects of concurrent training on muscle strength in older adults with metabolic syndrome: A randomized controlled clinical trial. Archives of Gerontology and Geriatrics, 75, 158-164. https:// doi.org/10.1016/j.archger.2017.12.011

Alves,W.M.,Alves,T. G., Ferreira, R. M., Lima,T.A., Pimentel, C. P., Sousa, E. C., Abrahin, O., \& Alves, E. A. (2019). Strength training improves the respiratory muscle strength and quality of life of elderly with Parkinson disease. Journal of Sports Medicine and Physical Fitness, 59(10), 1756-1762. https: / / doi.org/ 10.23736/S0022-4707.19.09509-4

Antunes, H. K. M., De Mello, M.T., DeAquino Lemos, V., SantosGalduróz, R. F., Galdieri, L. C., Bueno, O. F. A., Tufik, S., \& D’Almeida, V. (2015). Aerobic physical exercise improved the cognitive function of elderly males but did not modify their blood homocysteine levels. Dementia and Geriatric Cognitive Disorders Extra, 5(1), 13-24. https://doi.org/ 10.1159/000369160

Aragão-Santos, J. C., De Resende-Neto, A. G., Nogueira, A. C., Feitosa-Neta, M. de L., Brandão, L. H., Chaves, L. M., \& Da Silva-Grigoletto, M. E. (2019). The effects of functional and traditional strength training on different strength parameters of elderly women: A randomized and controlled trial. Journal of Sports Medicine and Physical Fitness, 59(3), 380-386. https: / /doi.org/10.23736/S0022-4707.18.08227-0

Arantes, P. M. M., Dias, J. M. D., Fonseca, F. F., Oliveira,A. M. B., Oliveira, M. C., Pereira, L. S.M., \& Dias, R. C. (2015). Effect of a Program Based on Balance Exercises on Gait, Functional Mobility, Fear of Falling, and Falls in Prefrail OlderWomen. Topics in Geriatric Rehabilitation, 31(2), 113-120. https: / / doi.org/10.1097/TGR.0000000000000056

Araque-Martínez, M. Á., Ruiz-Montero, P. J., \& Artés-Rodríguez, E. M. (2020). Efectos de un programa de ejercicio físico multicomponente sobre la condición física, la autoestima, la ansiedad y la depresión de personas adultas-mayores (Effects of a multicomponent physical exercise program on fitness, self-esteem, anxiety and depres. Retos, 39, 1024-1028. https:/ /doi.org/10.47197/retos.v0i39.83282

Aveiro, M. C.,Avila, M.A., Pereira-Baldon,V.S., Ceccatto Oliveira, A. S. B., Gramani-Say, K., Oishi, J., \& Driusso, P. (2017).Waterversus land-based treatment for postural control in postmenopausal osteoporotic women: a randomized, controlled trial. Climacteric, 20(5), 427-435. https: / / doi.org/ 10.1080/13697137.2017.1325460

Bacha, J.M.R., Gomes, G. C.V., De Freitas,T. B.,Viveiro,L.A.P., Da Silva, K. G., Bueno, G. C., Varise, E. M., Torriani-Pasin, C., Alonso,A.C., Luna, N. M. S., D’andrea Greve,J.M., \& Pompeu, J. E. (2018). Effects of kinect adventures games versus conventional physical therapy on postural control in elderly people:A randomized controlled trial. Games for Health Journal, 7(1), 24 -36. https://doi.org/10.1089/g4h.2017.0065

Barbalho, M.de S. M., Gentil, P., Izquierdo, M., Fisher, J., Steele, J., \& Raiol, R. de A. (2017). There are no no-responders to low or high resistance training volumes among older women. Experimental Gerontology, 99, 18-26. https://doi.org/10.1016/ j.exger.2017.09.003

Barbosa Rezende,A.A., Fernandes De Miranda, E., Souza Ramalho, H., Borges Da Silva, J.D., Silva Carlotto Herrera, S.D., Rossone Reis, G., \& Martin Dantas, E. H. (2015). Effects of sensory motor training of lower limb in sedentary elderly as part of functional autonomy. Revista Andaluza de Medicina Del Deporte, 8(2), 61-66. https://doi.org/10.1016/ j.ramd.2014.05.001

Botton, C.E., Umpierre, D., Rech,A., Pfeifer, L. O., Machado, C. L. F., Teodoro, J. L., Dias,A.S., \& Pinto, R. S. (2018). Effects of resistance training on neuromuscular parameters in elderly with type 2 diabetes mellitus: A randomized clinical trial. Experimental Gerontology, 113, 141-149. https://doi.org/ 10.1016/j.exger.2018.10.001

Brandão, G. S., Gomes, G. S. B. F., Brandão, G. S., Callou Sampaio, A.A., Donner, C. F., Oliveira, L.V.F., \& Camelier,A.A. (2018). Home exercise improves the quality of sleep and daytime sleepiness of elderlies: A randomized controlled trial. Multidisciplinary Respiratory Medicine, 13(1). https://doi.org/ 10.1186/s40248-017-0114-3

Bueno, G.A. S., Menezes, R. L. de, Vilela Lemos,T., \& Gervásio, F. M. (2018). Relationship of muscle strength with static balance in elderly-comparison between pilates and multimodalities. Revista Brasileira de Ciencias Do Esporte, 40(4), 435-441. https: / /doi.org/10.1016/j.rbce.2018.04.008

Buffart, L.M., Galvão,D.A., Brug, J., Chinapaw,M. J.M., \& Newton, R. U. (2014). Evidence-based physical activity guidelines for cancer survivors: Current guidelines, knowledge gaps and future research directions. In Cancer Treatment Reviews (Vol. 40, Issue 2, pp. 327-340). Elsevier. https://doi.org/10.1016/ j.ctrv.2013.06.007

Cadore, E. L., Menger, E., Teodoro, J. L., da Silva, L. X. N., Boeno, F.P., Umpierre, D., Botton, C.E., Ferrari, R., Cunha, G. dos S., Izquierdo, M., \& Pinto, R. S. (2018). Functional and physiological adaptations following concurrent training using sets with and without concentric failure in elderly men: A randomized clinical trial. Experimental Gerontology, 110, 182190. https://doi.org/10.1016/j.exger.2018.06.011

Campos De Oliveira, L., Gonçalves De Oliveira, R., \& DeAlmeida Pires-Oliveira, D. A. (2015). Effects of pilates on muscle strength, postural balance and quality of life of older adults: A randomized, controlled, clinical trial. Journal of PhysicalTherapy Science, 27(3), 871-876. https://doi.org/10.1589/ jpts. 27.871

Carvalho, I. F. De, Leme, G. L. M., \& Scheicher, M.E. (2018). The Influence ofVideo GameTraining with and without Subpatelar Bandage in Mobility and Gait Speed on Elderly Female Fallers. Journal of Aging Research, 2018. https://doi.org/10.1155/ 2018/9415093

Carvalho, M. J., Marques, E., \& Mota, J. (2009). Training and detraining effects on functional fitness after a multicomponent training in older women. Gerontology, 55(1), 41-48. https: / / 
doi.org/10.1159/000140681

Cavalcante, E. F., Ribeiro,A.S., Do Nascimento, M.A., Silva,A.M., Tomeleri, C.M., Nabuco,H. C. G., Pina, F. L. C., Mayhew, J.L., Da Silva-Grigoletto, M. E., Da Silva, D. R. P., Fleck, S. J., \& Cyrino, E. S. (2018). Effects of Different Resistance Training Frequencies on Fat in Overweight/Obese Older Women. International Journal of Sports Medicine, 39(7), 527-534. https: / /doi.org/10.1055/a-0599-6555

Coelho-Júnior, H. J., de Oliveira Gonçalvez, I., Sampaio, R.A. C., Sewo Sampaio, P.Y., Cadore, E. L., Izquierdo, M., Marzetti, E., \& Uchida, M. C. (2019). Periodized and non-periodized resistance training programs on body composition and physical function of older women. Experimental Gerontology, 121, 10 18. https://doi.org/10.1016/j.exger.2019.03.001

Costantino, S., Paneni, F., \& Cosentino, F. (2016). Ageing, metabolism and cardiovascular disease. The Journal of Physiology, 594(8), 2061-2073. https://doi.org/10.1113/JP270538

Cunha, P. M., Ribeiro, A. S., Nunes, J. P., Tomeleri, C. M., Nascimento, M.A., Moraes, G. K., Sugihara, P., Barbosa, D. S., Venturini, D., \& Cyrino, E. S. (2019). Resistance training performed with single-set is sufficient to reduce cardiovascular risk factors in untrained older women:Therandomized clinical trial.Active Aging Longitudinal Study. Archives of Gerontology and Geriatrics, 81, 171-175. https://doi.org/10.1016/ j.archger.2018.12.012

da Silva,L.A., Tortelli,L., Motta, J., Menguer, L., Mariano, S., Tasca, G., Silveira, G. de B., Pinho, R. A., \& Silveira, P. C. L. (2019). Effects of aquatic exercise on mental health, functional autonomy and oxidative stress in depressed elderly individuals: A randomized clinical trial. Clinics, 74. https://doi.org/ 10.6061/clinics/2019/e322

Da Silva, M. A. R., Baptista, L. C., Neves, R. S., De França, E., Loureiro, H., Rezende, M. D.A. C., Ferreira,V. da S., Veríssimo, M.T., \& Martins, R.A. (2019). High intensity interval training improves health-related quality of life in adults and older adults with diagnosed cardiovascular risk. Journal of Physical Education and Sport, 19(1), 611-618. https://doi.org/10.7752/ jpes.2019.01089

Da Silva, P. B., Antunes, F. N., Graef, P., Cechetti,F., \& Pagnussat,A. D. S. (2015). Strength training associated with task-oriented training to enhance upper-limb motor function in elderly patients with mild impairment after stroke: A randomized controlled trial. American Journal of Physical Medicine and Rehabilitation, 94(1), 11-19. https://doi.org/10.1097/ PHM.0000000000000135

Da Silveira Fontenele De Meneses,Y.P., Cabral, P. U. L., Orsano, F. E., \& Da Silveira, C. M. L. (2019).Vascular function and nitrite levels in elderly women before and after hydrogymnastics exercises. Journal of Physical Education (Maringa), 30(1), 3044. https: / /doi.org/10.4025/jphyseduc.v30i1.3044

Damorim, I. R., Santos, T. M., Barros, G.W.P., \& Carvalho, P.R. C. (2017). Kinetics of hypotension during 50 sessions of resistance and aerobic training in hypertensive patients: A randomized clinical trial. Arquivos Brasileiros de Cardiologia, 108(4), 323
330. https://doi.org/10.5935/abc. 20170029

Dantas, F.F. O., Do Socorro Brasileiro-Santos, M., Batista, R. M. F., Do Nascimento, L. S., Castellano, L. R. C., Ritti-Dias, R. M., Lima, K. C., \& Da Cruz Santos, A. (2016). Effect of strength training on oxidative stress and the correlation of the same with forearm vasodilatation and blood pressure of hypertensive elderly women: A randomized clinical trial. PLoS ONE, 11(8). https:/ / doi.org/10.1371/journal.pone.0161178

de Carvalho Fonseca, R. G., Silva, A. M., Teixeira, L. F., Silva,V. R., dos Reis, L. M., \& Silva Santos, A. T. (2018). Effect of the Auricular Acupoint Associated with Physical Exercise in Elderly People: A Randomized Clinical Test. JAMS Journal of Acupuncture and Meridian Studies, 11(4), 137-144. https:// doi.org/10.1016/j.jams.2018.05.003

de Lima,T.A., Ferreira-Moraes, R.,Alves,W.M. G. da C.,Alves,T. G. G., Pimentel, C. P., Sousa, E. C., Abrahin, O., \& CortinhasAlves, E. A. (2019). Resistance training reduces depressive symptoms in elderly people with Parkinson disease: A controlled randomized study. Scandinavian Journal of Medicine and Science in Sports, 29(12), 1957-1967. https://doi.org/ $10.1111 /$ sms. 13528

De Oliveira, D. V., Da Cunha, P. M., Dos Santos Campos, R., Do Nascimento, M.A.,Antunes, M. D., Do Nascimento, J. R.A., Mayhew, J. L., \& Cavaglieri, C. R. (2019). Effect of circuit resistance training on blood biomarkers of cardiovascular disease risk in older women. Journal of Physical Education (Maringa), 30(1). https://doi.org/10.4025/ jphyseduc.v30i1.3053

De Oliveira, R.T., Felippe, L.A., Gobbi, L.T. B., Barbieri, F.A., \& Christofoletti, G. (2017). Benefits of Exercise on the Executive Functions in People with Parkinson Disease. American Journal of Physical Medicine and Rehabilitation, 96(5), 301-306. https: / /doi.org/10.1097/PHM.0000000000000612

de Oliveira Silva, F., Ferreira, J.V., Plácido, J., Sant’Anna, P., Araújo, J., Marinho, V., Laks, J., \& Camaz Deslandes,A. (2019).Three months of multimodal training contributes to mobility and executive function in elderly individuals with mild cognitive impairment, but not in those with Alzheimer's disease: A randomized controlled trial. Maturitas, 126, 28-33. https: / / doi.org/10.1016/j.maturitas.2019.04.217

De Oliveira,V.H., Câmara, G. L. G., Azevedo, K.P.M., Neto, E. C. A., Dos Santos, I. K., Medeiros, H. J., \& Knackfuss, M.I. (2019). Weight training program with imposed and self-selected intensity on body composition in elderly:A randomized clinical trial. Revista Andaluza de Medicina Del Deporte, 12(1), 11-14. https://doi.org/10.33155/j.ramd.2018.05.001

deQueiroz, J.L., Sales, M. M., Sousa, C.V., da SilvaAguiar, S.,Asano, R.Y., de Moraes, J. F.V. N., Soares, B. R.A., Neves, R.V.P., de Moraes, M. R., \& Simões, H. G. (2016). 12 weeks of Brazilian jiu-jitsu training improves functional fitness in elderly men. Sport Sciences for Health, 12(3), 291-295. https://doi.org/ 10.1007/s11332-016-0287-8

de Resende-Neto, A. G., Oliveira Andrade, B. C., Cyrino, E. S., Behm, D. G., De-Santana, J. M., \& Da Silva-Grigoletto, M.E. 
(2019). Effects of functional and traditional training in body composition and muscle strength components in older women: A randomized controlled trial. Archives of Gerontology and Geriatrics, 84. https://doi.org/10.1016/ j.archger.2019.103902

De Resende Neto,A. G., De Lourdes Feitosa Neta, M., Santos, M. S.,LaScalaTeixeira, C.V., DeSá, C.A., \& Da Silva-Grigoletto, M. E. (2016). Functional training versus traditional strength training: Effects on physical fitness indicators in pre-frail elderly women. Motricidade, 12(December), 44-53.

Di Lorito, C., Bosco,A., Booth, V., Goldberg, S., Harwood, R. H., \&Van derWardt,V.(2020).Adherence to exercise interventions in older people with mild cognitive impairment and dementia: A systematic review and meta-analysis. In Preventive Medicine Reports (Vol. 19, p. 101139). Elsevier Inc. https://doi.org/ 10.1016/j.pmedr.2020.101139

Dias, C. P.,Toscan, R., de Camargo, M., Pereira, E. P., Griebler, N., Baroni, B. M., \&Tiggemann, C. L. (2015). Effects of eccentricfocused and conventional resistance training on strength and functional capacity of older adults. Age, 37(5). https: / / doi.org/ 10.1007/s11357-015-9838-1

Dirección de Promoción de la Salud y Control De Enfermedades No Transmisibles. (2013). Manual director de actividad fisica y salud de la república de Argentina. https: / / cesni-biblioteca.org/ wp-content/uploads / 2020/04/manu00l-de-laplenitudDDD_optimize.pdf

Dos Santos, L., Ribeiro, A. S., Cavalcante, E. F., Nabuco, H. C., Antunes, M., Schoenfeld, B. J., \& Cyrino, E. S. (2018). Effects of Modified Pyramid System on Muscular Strength and Hypertrophy in Older Women. International Journal of Sports Medicine, 39(8), 613-618. https://doi.org/10.1055/a0634-6454

Dueñas, E. P., Ramírez, L. P., Ponce, E., \& Curcio, C. L. (2019). Effect on fear of falling and functionality of three intervention programs. A randomised clinical trial. Revista Espanola de Geriatria y Gerontologia, 54(2), 68-74. https://doi.org/ 10.1016/j.regg.2018.09.013

Faber, M.J., Bosscher, R. J., ChinA Paw, M. J., \& vanWieringen, P. C. (2006). Effects of Exercise Programs on Falls and Mobility in Frail and Pre-Frail OlderAdults:A Multicenter Randomized Controlled Trial. Archives of Physical Medicine and Rehabilitation, 87(7), 885-896. https://doi.org/10.1016/ j.apmr.2006.04.005

Ferrari, R., Fuchs, S. C., Kruel, L.F.M., Cadore, E.L.,Alberton, C. L., Pinto, R. S., Radaelli, R., Schoenell, M., Izquierdo, M., Tanaka, H., \& Umpierre, D. (2016). Effects of different concurrent resistance and aerobic training frequencies on muscle power and muscle quality in trained elderly men: A randomized clinical trial. Aging and Disease, 7(6), 697-704. https://doi.org/10.14336/AD.2016.0504

Ferraz, D. D., Trippo, K.V., Duarte, G. P., Neto, M. G., Bernardes Santos, K. O., \& Filho, J. O. (2018). The Effects of Functional Training, Bicycle Exercise, and Exergaming on Walking Capacity of Elderly Patients With Parkinson Disease: A Pilot
Randomized Controlled Single-blinded Trial. Archives of Physical Medicine and Rehabilitation, 99(5), 826 833. https: / / doi.org/ 10.1016/j.apmr.2017.12.014

Ferreira, C. B., Teixeira, P.D. S., Alves Dos Santos, G., Dantas Maya, A.T.,Americano Do Brasil,P., Souza,V.C., Córdova, C., Ferreira, A.P.,Lima, R. M., \& Nóbrega, O. D.T. (2018). Effects of a 12 Week Exercise Training Program on Physical Function in Institutionalized Frail Elderly. Journal of Aging Research, 2018. https: / / doi.org/10.1155/2018/7218102

Ferreira, R. M.,Alves,W. M. G. da C., Lima,T.A., Alves, T. G. G., Alves Filho, P.A.M., Pimentel, C.P., Sousa, E. C., \& CortinhasAlves, E. A. (2018). The effect of resistance training on the anxiety symptoms and quality of life in elderly people with parkinson's disease: A randomized controlled trial. Arquivos de Neuro-Psiquiatria, 76(8), 499-506. https://doi.org/ 10.1590/0004-282x20180071

Findorff, M. J.,Wyman, J. F., \& Gross, C. R. (2009). Predictors of long-term exercise adherence in a community-based sample of older women. Journal of Women's Health, 18(11), 1769 1776. https://doi.org/10.1089/jwh.2008.1265

Fleg, J. L. (2012).Aerobic exercise in the elderly:A key to successful aging. Discovery Medicine, 13(70), 223-228. http:// europepmc.org/article/med/22463798

Forbes, C. C., Swan, F., Greenley, S. L., Lind, M., \& Johnson, M. J. (2020). Physical activity and nutrition interventions for older adults with cancer: a systematic review. In Journal of Cancer Survivorship (Vol. 14, Issue 5, pp. 689-711). Springer. https: / / doi.org/10.1007/s11764-020-00883-x

Franco, M. R., Sherrington, C., Tiedemann, A., Pereira, L. S., Perracini, M. R., Faria, C. R. S., Pinto, R. Z., \& Pastre, C. M. (2016). Effectiveness of Senior Dance on risk factors for falls in older adults (DanSE): A study protocol for a randomised controlled trial. BMJ Open, 6(12), 13995. https://doi.org/ 10.1136/bmjopen-2016-013995

Fraser, S. N., \& Spink, K. S. (2002). Examining the Role of Social Support and Group Cohesion in Exercise Compliance. Journal of Behavioral Medicine, 25(3), 233-249. https://doi.org/ 10.1023/A:1015328627304

Gadelha, A. B., Paiva, F. M. L., Gauche, R., de Oliveira, R. J., \& Lima, R. M. (2016). Effects of resistance training on sarcopenic obesity index in older women:A randomized controlled trial. Archives of Gerontology and Geriatrics, 65, 168-173. https:// doi.org/10.1016/j.archger.2016.03.017

Galloza, J., Castillo, B. \& \& Micheo,W. (2017). Benefits of Exercise in the Older Population. In Physical Medicine and Rehabilitation Clinics of North America (Vol. 28, Issue 4, pp. 659-669). W.B. Saunders. https://doi.org/10.1016/j.pmr.2017.06.001

Gambassi, B. B., Almeida, F. J. F., Sauaia, B. A., Novais, T. M. G., Furtado, A. E. A., Chaves, L. F. C., Rodrigues, B., Silva, A. R. M., Melo, L. P., \& Mostarda, C.T. (2015). Resistance training contributes to variability in heart rate and quality of the sleep in elderly women without comorbidities. Journal of Exercise Physiology Online, 18(6), 112-123.

Gobierno de Chile. (2017). Recomendaciones para la práctica de 
actividad física según curso de vida. http:// selloseligevivirsano.cl/wp-content/uploads/2019/03/ guia-de-recomendaciones-af-curso-de-vida.pdf

Gomeñuka, N.A., Oliveira, H. B., da Silva, E. S., Passos-Monteiro, E., da Rosa, R. G., Carvalho,A. R., Costa,R. R., RodríguezPaz, M. C., Pellegrini, B., \& Peyré-Tartaruga, L.A. (2020). Nordic walking training in elderly, a randomized clinical trial. Part II: Biomechanical and metabolic adaptations. Sports Medicine Open, 6(1). https://doi.org/10.1186/s40798-019-02286

Gomeñuka, N.A., Oliveira, H. B., Silva, E. S., Costa, R. R., Kanitz, A. C., Liedtke, G. V., Schuch, F. B., \& Peyré-Tartaruga, L.A. (2019). Effects of Nordic walking training on quality of life, balance and functional mobility in elderly: A randomized clinical trial. PLoS ONE, 14(1). https://doi.org/10.1371/ journal.pone.0211472

Gomes, R., Souza Vale, D. E., Ribeiro, D., Da Gama, N., Boechat De Oliveira, F., Sá, D., Almeida, D. M., Brandão, J., De Castro, P., Ismael, E., Meza, A., Da, R., Mattos, S., DeAlkmim, R., \& Nunes, M. (2018). Effects of resistance training and chess playing on the quality of life and cognitive performance of elderly women: a randomized controlled trial. Journal of Physical Education and Sport ${ }^{\circledR}(J P E S), 18(3), 1469-1477$. https:// doi.org/10.7752/jpes.2018.03217

Gonçalves, I. D. O., Bandeira,A.N., Coelho-Júnior, H.J., Aguiar, S. D. S., Camargo, S. M., Asano, R.Y., \& Batista Júnior, M. L. (2019). Multicomponent exercise on physical function, cognition and hemodynamic parameters of communitydwelling older adults:A quasi-experimental study. International Journal of Environmental Research and Public Health, 16(12). https:/ /doi.org/10.3390/ijerph16122184

Grupo Banco Mundial. (2019). Población mundial total. https:// datos.bancomundial.org/indicator/SP.POP.TOTL

Guedes, J. M., Bortoluzzi, M. G., Matte, L. P., Andrade, C. M. de, Zulpo, N. C., Sebben,V., \& Tourinho Filho, H. (2016). Effects of explosive and impact exercises on gait parameters in elderly women. Revista Brasileira de Medicina Do Esporte, 22(6), 480 484. https: //doi.org/10.1590/1517869220162206124834

Hall López, J.A., Ochoa Martínez,P.Y.,Alarcón Meza,E.I., MoncadaJiménez, J. A., Garcia Bertruy, O., \& Martin Dantas, E. H. (2017). Hydrogymnastics training program on physical fitness in elderly women. Hydrogymnastics Training Program on Physical Fitness in ElderlyWomen, 17(66), 283-298. https://doi.org/ 10.15366/rimcafd2017.66.005

Hancox, J.E., van derWardt,V., Pollock, K., Booth,V.,Vedhara, K., \& Harwood, R. H. (2019). Factors influencing adherence to home-based strength and balance exercises among older adults with mild cognitive impairment and early dementia: Promoting Activity, Independence and Stability in Early Dementia (PrAISED). PLOS ONE, 14(5), e0217387. https://doi.org/ 10.1371/journal.pone.0217387

Henrique, P. P. B., Colussi, E. L., \& De Marchi, A. C. B. (2019). Effects of Exergame on Patients' Balance and Upper Limb Motor Function after Stroke:A Randomized ControlledTrial.
Journal of Stroke and Cerebrovascular Diseases, 28(8), 2351-2357. h t t p s : / / d o i . org// $10.1016 /$ j.jstrokecerebrovasdis.2019.05.031

Herminia Gallo,L., LuizDemantova Gurjão,A., Gobbi, S., Ceccato, M., Konig Garcia Prado,A., Claudio Jambassi Filho, J., Raquel Silveira Gomes, A., Boone, T., Review Board Todd Astorino, M., Baker, J., Brock, S., Dalleck, L., Goulet, E., Gotshall, R., Hutchison, A., Knight-Maloney, M., Kravitz, L., Laskin, J., Aun Lim, Y., ... Zhou, B. (2015). Effects of Static Stretching on Functional Capacity in OlderWomen: Randomized Controlled Trial. 18.

Hill, K.D., Hunter, S.W., Batchelor, F.A., Cavalheri,V., \& Burton, E. (2015). Individualized home-based exercise programs for older people to reduce falls and improve physical performance: A systematic review and meta-analysis. In Maturitas (Vol. 82, Issue 1, pp. 72-84). Elsevier Ireland Ltd. https: / / doi.org/ 10.1016/j.maturitas.2015.04.005

Hong, S.Y., Hughes, S., \& Prohaska, T. (2008). Factors affecting exercise attendance and completion in sedentary older adults: A meta-analytic approach. Journal of Physical Activity and Health, 5(3), 385-397. https://doi.org/10.1123/jpah.5.3.385

Huang, C. Q., Dong, B. R., Lu, Z. C.,Yue, J. R., \& Liu, Q.X.(2010). Chronic diseases and risk for depression in old age: A metaanalysis of published literature. In Ageing Research Reviews (Vol. 9, Issue 2, pp. 131-141). Elsevier.https://doi.org/10.1016/ j.arr.2009.05.005

Landi, F., Marzetti, E., Martone,A. M., Bernabei, R., \& Onder, G. (2014). Exercise as a remedy for sarcopenia. In Current Opinion in Clinical Nutrition and Metabolic Care (Vol. 17, Issue 1, pp. $25-$ 31). Curr Opin Clin Nutr Metab Care. https://doi.org/ 10.1097/MCO.0000000000000018

Langoni, C. D. S., Resende, T. D. L., Barcellos,A. B., Cecchele, B., Knob, M. S., Silva,T.D. N., Da Rosa, J. N., Diogo,T.D. S., Filho, I. G. D. S., \& Schwanke, C.H.A. (2019). Effect of Exercise on Cognition, Conditioning, Muscle Endurance, and Balance in OlderAdults with Mild Cognitive Impairment:A Randomized ControlledTrial. Journal of Geriatric PhysicalTherapy, 42(2), E15E22. https://doi.org/10.1519/JPT.0000000000000191

Leal, L. C. P., Abrahin, O., Rodrigues, R. P., da Silva, M. C. R., Araújo,A.P.M., de Sousa, E. C., Pimentel, C. P., \& CortinhasAlves, E.A. (2019). Low-volume resistance training improves the functional capacity of older individuals with Parkinson's disease. Geriatrics and Gerontology International, 19(7), 635640. https://doi.org/10.1111/ggi.13682

Leandro, M. P. G., de Moura, J.L. S., Barros, G.W.P., da Silva Filho, A. P., Farias,A.C. de O., \& Carvalho, P. R. C. (2019). Effect of the aerobic component of combined training on the blood pressure of hypertensive elderly women. Revista Brasileira de Medicina Do Esporte, 25(6), 469-473. https://doi.org/ 10.1590/1517-869220192506214228

Liberati,A.,Altman, D. G., Tetzlaff, J., Mulrow, C., Gøtzsche, P. C., Ioannidis, J. P.A., Clarke, M., Devereaux, P. J., Kleijnen, J., \& Moher, D. (2009). The PRISMA Statement for Reporting Systematic Reviews and Meta-Analyses of StudiesThat Evaluate Health Care Interventions: Explanation and Elaboration. PLoS 
Medicine, 6(7), e1000100. https://doi.org/10.1371/ journal.pmed.1000100

Lima, L. G., Bonardi, J. M.T., Campos, G. O., Bertani, R. F., Scher, L. M. L., Louzada-Junior, P., Moriguti, J. C., Ferriolli, E., \& Lima, N. K. C. (2015). Effect of aerobic training and aerobic and resistance training on the inflammatory status of hypertensive older adults. Aging Clinical and Experimental Research, 27(4), 483-489. https://doi.org/10.1007/ s40520-014-0307-y

Lixandrão, M.E., Damas, F., Chacon-Mikahil, M. P.T., Cavaglieri, C.R., Ugrinowitsch, C., Bottaro, M.,Vechin, F. C., Conceição, M. S., Berton, R., \& Libardi, C. A. (2016). Time Course of Resistance Training-Induced Muscle Hypertrophy in the Elderly. Journal of Strength and Conditioning Research, 30(1), 159 163. https: / / doi.org/10.1519/JSC.0000000000001019

Lopes, P. B., Pereira, G., Lodovico,A., Bento, P. C. B., \& Rodacki, A. L. F. (2016). Strength and PowerTraining Effects on Lower Limb Force, Functional Capacity, and Static and Dynamic Balance in Older Female Adults. Rejuvenation Research, 19(5), 385-393. https://doi.org/10.1089/rej.2015.1764

López, N.,Véliz,A., Soto-Añari, M., Ollari, J., Chesta, S., \&Allegri, R. (2015). Effects of a combined program of physical activity and cognitive training in Chilean patients with mild Alzheimer. Neurologia Argentina, 7(3), 131-139. https://doi.org/ 10.1016/j.neuarg.2015.04.001

Lox, C. L., Ginis, K.A., \& Petruzzello, S. (2014). The Psychology of Exercise: Integrating Theory and Practice.

Martinez, A., Selaive, R., Astorga, S., \& Olivares, P. (2018). Neuromuscular training in institutionalized older adults: A functional approach to preventing fall. Nutricion Clinica $y$ Dietetica Hospitalaria, 38(3), 40-45. https://doi.org/ 10.12873/383martinez

Martins,W. R., Safons, M. P., Bottaro, M., Blasczyk, J. C., Diniz, L. R., Fonseca, R. M. C., Bonini-Rocha, A. C., \& De Oliveira, R. J. (2015). Effects of short term elastic resistance training on muscle mass and strength in untrained older adults: a randomized clinical trial. BMC Geriatrics, 15(1), 1-10. https: / /doi.org/10.1186/s12877-015-0101-5

Mazini Filho, M.L.,Aidar,F.J., Costa Moreira, O., GamaDe Matos, D.,Patrocínio De Oliveira, C.E., RezendeDe OliveiraVenturini, G., De Paula Costa, S., Magalhães Curty,V., \& Caputo Ferreira, M. E. (2017). Comparison of the effect of two physical exercise programs on the functional autonomy, balance and flexibility of elderly women. Medicina Dello Sport, 70(3), 288-298.https:/ /doi.org/10.23736/S0025-7826.17.03012-5

McGowan, J., Sampson, M., Salzwedel, D. M., Cogo, E., Foerster, V., \& Lefebvre, C. (2016). PRESS Peer Review of Electronic Search Strategies: 2015 Guideline Statement. Journal of Clinical Epidemiology, 75, 40-46. https://doi.org/10.1016/ j.jclinepi.2016.01.021

McPhee, J.S., French, D. P., Jackson, D., Nazroo, J., Pendleton, N., \& Degens, H. (2016). Physical activity in older age: perspectives for healthy ageing and frailty. In Biogerontology (Vol. 17, Issue 3, pp. 567-580). Springer Netherlands. https://doi.org/ $10.1007 / \mathrm{s} 10522-016-9641-0$
Medeiros, L. B., Ansai, J.H., De Souza Buto, M. S., Barroso,V. deV., Farche,A. C. S., Rossi, P. G., deAndrade,L.P., \&Takahashi,A. C. de M. (2018). Impact of a dual task intervention on physical performance of older adults who practice physical exercise. Revista Brasileira de Cineantropometria e Desempenho Humano, 20(1), 10-19. https://doi.org/10.5007/19800037.2018v20n1p10

Medina-Mirapeix, F., Escolar-Reina, P., Gascón-Cánovas, J. J., Montilla-Herrador, J., \& Collins, S. M. (2009). Personal characteristicsinfluencing patients' adherence to home exercise during chronic pain: A qualitative study. Journal of Rehabilitation Medicine, 41(5), 347-352. https://doi.org/10.2340/ 16501977-0338

Ministerio de Salud Pública del Ecuador. (2011). Guía de actividad física dirigida al personal de salud II. https:// aplicaciones.msp.gob.ec/salud/archivosdigitales / documentosDirecciones/dnn/archivos/GUIA DE ACTIVIDAD FISICA 2.pdf

Miranda-Aguilar, D., Valdés-Badilla, P., Herrera-Valenzuela, T., Guzmán-Muñoz, E., Branco, B. H. M., Méndez-Rebolledo, G., \& López-Fuenzalida, A. (2019). Elastic bands or gym equipment for the training of older adults? Retos, 40(9), 370 378. https: / / doi.org/10.47197/RETOS.V37I37.73009

Mitnitski, A. B., Graham, J. E., Mogilner, A. J., \& Rockwood, K. (2002). Frailty, fitness and late-life mortality in relation to chronological and biological age. BMC Geriatrics, 2(1), 1-8. https: / /doi.org/10.1186/1471-2318-2-1

Monteiro-Junior, R. S., Figueiredo, L. F. d. S., Maciel-Pinheiro, P. deT.,Abud,E. L. R., Engedal, K., Barca, M. L., Nascimento, O. J. M., Laks, J., \& Deslandes, A. C. (2017). Virtual RealityBased Physical Exercise With Exergames (PhysEx) Improves Mental and Physical Health of Institutionalized Older Adults. In Journal of the American Medical Directors Association (Vol. 18, Issue 5, pp. 454.e1-454.e9). Elsevier Inc. https://doi.org/ 10.1016/j.jamda.2017.01.001

Mora, J. C., \&Valencia,W. M. (2018). Exercise and Older Adults. In Clinics in Geriatric Medicine (Vol. 34, Issue 1, pp. 145-162). W.B. Saunders. https://doi.org/10.1016/ j.cger.2017.08.007

MoreiraAntunes, H., Santos-Galduroz, R. F., De Aquino Lemos, V., Bueno, O. F.A., Rzezak, P., de Santana, M. G., \& De Mello, M. T. (2015). The influence of physical exercise and leisure activity on neuropsychological functioning in older adults. Age, 37(4). https://doi.org/10.1007/s11357-015-98158

Moreira, N. B., Gonçalves, G., da Silva, T., Zanardini, F. E. H., \& Bento, P. C. B. (2018). Multisensory exercise programme improves cognition and functionality in institutionalized older adults: A randomized control trial. Physiotherapy Research International, 23(2). https://doi.org/10.1002/pri.1708

Nacional Costa Rica, U., Valenzuela, C., Elena, M., Jacobo, B., Fernández, G., Arnoldo,D., Vega, F., de los Ángeles, M., Perkins, O., Ernesto, C., Del Cid, M., Eduardo, E., Ruíz, H., \& Aplicación De Un Programa De Intervención Para El Beneficio De La Salud FísicaY, G. LA. (2018). La aplicación de un programa de 
intervención para el beneficio de la salud fisica y emocional en mujeres adultas mayores en Hermosillo, Sonora. 15(1). https: / / doi.org/ 10.15359/mhs.15-1.4

Nascimento, M.A. Do, Gerage,A. M., Silva, D. R.P.Da, Ribeiro,A. S., Machado,D. G. D.S., Pina,F.L.C., Tomeleri, C.M.,Venturini, D., Barbosa, D. S., Mayhew, J.L., \& Cyrino, E. S. (2019). Effect of resistance training with different frequencies and subsequent detraining on muscle mass and appendicular lean soft tissue, IGF-1, and testosterone in older women. European Journal of Sport Science, 19(2), 199-207. https://doi.org/10.1080/ 17461391.2018.1496145

Neta, M. de L. F., Resende-Neto, A. G. de, Dantas, E. H. M., Almeida, M. B. de,Wichi, R. B., \& Silva-Grigoletto, M.E. Da. (2016). Effects of functional training on strength, muscle power and quality of life in pre-frail older women/Efeitos do treinamento funcional na forca, potencia muscular e qualidade de vida deidosas pre-frageis. Motricidade, 12(S2), 61-69.https:/ $/$ go.gale.com $/$ ps $/$ i.do?p $=$ IFME\&sw $={ }_{w} \&$ issn $=16$ 46107X\&v $=2.1 \& \mathrm{it}=\mathrm{r} \& \mathrm{id}=\mathrm{GALE} \%$ 7CA500197462\&sid $=\mathrm{g}$ oogleScholar\&linkaccess $=$ fulltext

Neto,A. G. deR., Santos, M.S., Silva, R. J.S., de Santana,J.M., \& da Silva-Grigoletto, M. E. (2018). Effects of different neuromuscular training protocols on the functional capacity of elderly women. Revista Brasileira de Medicina Do Esporte, 24(2), 140-144. https://doi.org/10.1590/1517869220182402167781

Nicolson, P. J.A., Bennell, K. L., Dobson, F. L., Van Ginckel, A., Holden, M. A., \& Hinman, R. S. (2017). Interventions to increase adherence to therapeutic exercise in older adults with low back pain and/or hip/knee osteoarthritis: A systematic review and meta-analysis. In British Journal of Sports Medicine (Vol. 51, Issue 10, pp. 791-799). BMJ Publishing Group. https: / /doi.org/10.1136/bjsports-2016-096458

Oliveira-Dantas, F. F., Brasileiro-Santos, M. do S., Thomas, S. G., Silva, A. S., Silva, D. C., Browne, R. A.V., Farias-Junior, L. F., Costa,E. C., \& da Cruz Santos,A. (2020). Short-term resistance training improves cardiac autonomic modulation and blood pressure in hypertensive older women: A randomized controlled trial. Journal of Strength and Conditioning Research, 34(1), 37-45. https://doi.org/10.1519/ jsc.0000000000003182

Oliveira, L. C. de, Oliveira, R. G. de, \& Pires-Oliveira, D.A. deA. (2016). Comparison between static stretching and the Pilates method on the flexibility of older women. Journal of Bodywork and Movement Therapies, 20(4), 800-806. https://doi.org/ 10.1016/j.jbmt.2016.01.008

Ortiz-ortiz, M., Gómez-miranda, L. M., Chacón-araya, Y., \& Moncada-jiménez, J. (2019). Effects of a physical activity program on depressive symptoms and functional capacity of institutionalized Mexican older adults. Journal of Physical Education and Sport ${ }^{\circledR}$ (JPES), 19, 890-896. https: / /doi.org/ 10.7752/jpes.2019.s3128

Patino, C. M., \& Ferreira, J. C. (2018). Inclusion and exclusion criteria in research studies: Definitions and why they matter. In Jornal Brasileiro de Pneumologia (Vol.44, Issue 2, p. 84). Sociedade
Brasileira de Pneumologia e Tisiologia. https://doi.org/ 10.1590/s1806-37562018000000088

Peranovich, A. C. (2016). Enfermedades crónicas y factores de riesgo en adultos mayores de Argentina: años 2001 - 2009. Saúde Em Debate, 40(109), 125-135. https://doi.org/ 10.1590/0103-1104201610910

Pestana, M. D. S., Netto, E. M., Pestana, M. C. S., Pestana, V. S., \& Schinoni, M. I. (2016). Pilates versus resistance exercise on the serum levels of hs-CRP, in the abdominal circumference and body mass index (BMI) in elderly individuals. Motricidade, 12(1), 128-140. https://doi.org/10.6063/ motricidade. 6682

Picorelli, A. M. A., Pereira, L. S. M., Pereira, D. S., Felício, D., \& Sherrington, C. (2014). Adherence to exercise programs for older people is influenced by program characteristics and personal factors:A systematic review. Journal of Physiotherapy, 60(3), 151-156. https://doi.org/10.1016/j.jphys.2014.06.012

Pirauá,A.L.T., Cavalcante, B.R., de Oliveira,V.M.A., Beltrão, N. B., de Amorim Batista, G., Pitangui, A. C. R., Behm, D., \& de Araújo, R. C. (2019). Effect of 24-week strength training on unstable surfaces on mobility, balance, and concern aboutfalling in older adults. Scandinavian Journal of Medicine and Science in Sports, 29(11), 1805-1812. https://doi.org/10.1111/ sms. 13510

Porzsolt, F., Wiedemann, F., Becker, S. I., \& Rhoads, C. J. (2019). Inclusion and exclusion criteria and the problem of describing homogeneity of study populations in clinical trials. BMJEvidenceBased Medicine, 24(3), 92-94. https://doi.org/10.1136/ bmjebm-2018-111115

Ramirez-Campillo, R., Alvarez, C., Garcia-Hermoso, A., CelisMorales, C., Ramirez-Velez, R., Gentil, P., \& Izquierdo, M. (2018). High-speed resistance training in elderly women: Effects of cluster training sets on functional performance and quality of life. Experimental Gerontology, 110, 216-222. https: / /doi.org/10.1016/j.exger.2018.06.014

Ramirez-Campillo, R., Diaz, D., Martinez-Salazar, C., Valdés-Badilla, P., Delgado-Floody, P., Méndez-Rebolledo, G., Cañas-Jamet, R., Cristi-Montero, C., García-Hermoso, A., Celis-Morales, C., Moran, J., Buford, T. W., Rodriguez-Mañas, L., AlonsoMartinez,A. M., \& Izquierdo, M. (2016). Effects of different doses of high-speed resistance training on physical performance and quality of life in older women: A randomized controlled trial. Clinical Interventions in Aging, 11, 1797-1804. https: / / doi.org/10.2147/CIA.S121313

Ramírez-Villada, J., Cadena-Duarte,L., \& Lorena Rocío GutiérrezGalvis, Adriana Argothy-Bucheli, Rodrigo Moreno-Ramírez, Y. (2019). Effects of explosive and impact exercises on gait parameters in elderly women. Rev. Fac. Med, 67(4), 493-501. https://doi.org/10.15446/revfacmed.v67n4.75051

Ribeiro, A. S., Schoenfeld, B. J., Pina, F. L. C., Souza, M. F., Nascimento, M.A., Dos Santos, L.,Antunes, M., \& Cyrino, E. S. (2015). Resistance training in older women: Comparison of single vs. multiple sets on muscle strength and body composition. Isokinetics and Exercise Science, 23(1), 53-60. https://doi.org/10.3233/IES-140564 
Ribeiro,A. S., Schoenfeld, B. J., Souza, M. F., Tomeleri, C. M., Silva, A. M., Teixeira, D. C., Sardinha, L. B., \& Cyrino, E. S. (2017). Resistance training prescription with different loadmanagement methods improves phase angle in older women. European Journal of Sport Science, 17(7), 913-921. https:// doi.org/10.1080/17461391.2017.1310932

Ribeiro, A. S., Schoenfeld, B. J., Souza, M. F., Tomeleri, C. M., Venturini,D., Barbosa, D. S., \& Cyrino, E. S. (2016).Traditional and pyramidal resistance training systems improve muscle quality and metabolic biomarkers in older women: A randomized crossover study. Experimental Gerontology, 79, 8 15. https://doi.org/10.1016/j.exger.2016.03.007

Rico-Gallegos, C., Carrillo-Sánchez, J. L., Vargas-Esparza, G., \& Poblete-Valderrama, F. (2020). Programa de intervención basado en VIVIFRAIL para mejorar la funcionalidad de adultos mayores. Revista Peruana de Ciencia de LaActividad Fisica y Del Deporte. https://www.rpcafd.com/index.php/rpcafd/article/ view/101/154

Rodacki,A. L. F., Cepeda, C. P. C., Lodovico,A., \& Ugrinowitsch, C. (2017). The Effects of a Dance-Based Program on the Postural Control in Older Women. Topics in Geriatric Rehabilitation, 33(4), 244-249. https://doi.org/10.1097/ TGR.0000000000000166

Rodrigues-Krause,J., Farinha, J. B., Ramis,T.R., Macedo, R. C. O., Boeno, F. P., dos Santos, G. C., Vargas, J., Lopez, P., Grazioli, R., Costa, R. R., Pinto, R. S., Krause, M., \& Reischak-Oliveira,A. (2018). Effects of dancing compared to walking on cardiovascular risk and functional capacity of older women: A randomized controlled trial. Experimental Gerontology, 114, 6777. https: / /doi.org/10.1016/j.exger.2018.10.015

Romero Ramos, N., Romero-Ramos, Ó., \& González Suárez,A. J. (2020). Actividad física y funciones cognitivas en personas mayores: revisión sistemática de los últimos 5 años (Physical activity and cognitive functions in older people: a systematic review of the last 5 years). Retos, 39. https://doi.org/ 10.47197/retos.v0i39.79960

Rosa, C., Vilaça-alves, J., Neves, E. B., José, F., Saavedra, F., Reckziegel, M. B., Pohl,H.H.,Zanini, D., \& Reis, V.M.(2017). The effect of weekly low frequency exercise on body composition and blood pressure of elderly women. Arch Med Deporte, 34(1), 9-14.

Ruaro, M. F., Oliveira Santana, J., Gusmão, N., De França, E., Carvalho, B. N., Farinazo, K. B., Lencina Bonorino, S., Corralo, V., De Sá,A., \& Caperuto 10,É. C. (2019). Effects of strength training with and without blood flow restriction on quality of life in elderly women. Journal of Physical Education and Sport $\mathbb{R}$ (JPES), 19(1), 531-539. https://doi.org/10.7752/ jpes.2019.01078

Salinas C, J., Bello S, M., Flores C,A., Carbullanca L, L., \&Torres G, M. (2005).Actividad física integral con adultos y adutos mayores en Chile: Resultados de un programa piloto. Revista Chilena de Nutrición, 32(3), 215-224. https://doi.org/10.4067/ s0717-75182005000300006

Santana, M., Pina, J., Duarte, G., Neto, M., Machado, A., \& Dominguez-Ferraz, D. (2016). Nintendo Wii effects on cardiorespiratory fitness in older adults: A randomized clinical trial.A pilot trial. Fisioterapia, 38(2), 71-77.https://doi.org/ 10.1016/j.ft.2015.03.003

Santiago, L. Íngelo M., Neto, L. G. L., Pereira, G. B., Leite, R. D., Mostarda, C.T., De Oliveira Brito Monzani, J., Sousa, W. R., Pinheiro,A.J.M. R., \& Navarro, F. (2018). Effects of resistance training on immunoinflammatory response, TNF-alpha gene expression, and body composition in elderly women. Journal of Aging Research, 2018. https://doi.org/10.1155/2018/ 1467025

Santos, G. D., Nunes, P.V., Stella, F., Brum, P.S.,Yassuda, M. S., Ueno, L. M., Gattaz,W. F., \& Forlenza, O.V.(2015). Multidisciplinary rehabilitation program: Effects of a multimodal intervention for patients withAlzheimer's disease and cognitive impairment without dementia. Revista de Psiquiatria Clinica, 42(6), 153 156. https: / / doi.org/10.1590/0101-60830000000066

Santos, G. O. R.,Wolf, R., Silva, M. M., Rodacki,A.L. F., \& Pereira, G. (2019). Does exercise intensity increment in exergame promote changes in strength, functional capacity and perceptual parameters in pre-frail older women? A randomized controlled trial. Experimental Gerontology, 116, 25-30. https: / /doi.org/10.1016/j.exger.2018.12.009

Santos, S. M., Da Silva, R.A., Terra, M. B., Almeida, I.A., De Melo, L. B., \& Ferraz, H. B. (2017). Balance versus resistance training on postural control in patients with Parkinson's disease: A randomized controlled trial. European Journal of Physical and Rehabilitation Medicine, 53(2), 173-183. https://doi.org/ 10.23736/S1973-9087.16.04313-6

Sbardelotto, M. L., Pedroso, G. S., Pereira, F. T., Soratto, H. R., Brescianini, S. M. S., Effting, P. S., Thirupathi, A., Nesi, R. T., Silveira, P. C. L., \& Pinho, R. A. (2017). The effects of physical training are varied and occur in an exercise type-dependent manner in elderly men. Aging and Disease, 8(6), 887-898. https://doi.org/10.14336/AD.2017.0209

Scarabottolo, C. C., Garcia Júnior, J. R., Gobbo, L.A., Alves, M. J., Ferreira, A. D., Zanuto, E. A. C., de Oliveira, W. G. A., \& Christofaro, D. G. D. (2017). Influence of physical exercise on the functional capacity in institutionalized elderly. Revista Brasileira de Medicina Do Esporte, 23(3), 200-203. https:// doi.org/10.1590/1517-869220172303150175

Secretaria Nacional Del Deporte. (2018). Programa Nacional de Educación Física para Personas Adultas Mayores.

Silva, C. M. daS. e., Gomes Neto, M., Saquetto, M. B., Conceição, C. S. da, \& Souza-Machado, A. (2018). Effects of upper limb resistance exercise on aerobic capacity, muscle strength, and quality of life in COPD patients: a randomized controlled trial. Clinical Rehabilitation, 32(12), 1636-1644. https://doi.org/ 10.1177/0269215518787338

Silva, R. G. da, Silva, D. R.P.da, Pina, F. L. C., Nascimento, M.A.do, Ribeiro, A. S., \& Cyrino, E. S. (2017). Effect of two different weekly resistance training frequencies on muscle strength and blood pressure in normotensive older women. Brazilian Journal of Kinanthropometry and Human Performance, 19(1), 118. https: / /doi.org/10.5007/1980-0037.2017v19n1p118

Silva, I. G., Silva, B. S. de A., Freire, A. P. C. F., Santos, A. P. S. dos, 
Lima, F. F. de, Ramos, D., \& Ramos, E. M. C. (2018). Functionality of patients with Chronic Obstructive Pulmonary Disease at 3 months follow-up after elastic resistance training: a randomized clinical trial. In Pulmonology (Vol. 24, Issue 6, pp. 354-357). Elsevier Espana S.L.U. https://doi.org/ 10.1016/j.pulmoe.2018.09.005

Silva, M. R., Alberton, C.L., Portella, E. G., Nunes, G. N., Martin, D. G., \& Pinto, S. S. (2018).Water-based aerobic and combined training in elderly women: Effects on functional capacity and quality of life. Experimental Gerontology, 106, 54 60. https:// doi.org/10.1016/j.exger.2018.02.018

Simao, A. P., Mendonca, V. A., Avelar, N. C. P., Fonseca, S. F. Da, Santos, J.M., Oliveira,A. C. C., Tossige-Gomes, R., Ribeiro,V. G. C., Neves, C. D. C., Balthazar, C.H., Leite,H.R., Figueiredo, P.H.S., Bernardo-Filho, M., \& Lacerda,A. C. R. (2019).Whole body vibration training on muscle strength and brain-derived neurotrophic factor levels in elderly woman with knee osteoarthritis: A randomized clinical trial study. Frontiers in Physiology, 10(JUN). https://doi.org/10.3389/ fphys.2019.00756

Souza, D., Barbalho, M.,Vieira, C.A., Martins,W.R., Cadore,E.L., \& Gentil, P. (2019). Minimal dose resistance training with elastic tubes promotes functional and cardiovascular benefits to older women. Experimental Gerontology, 115, 132-138. https://doi.org/10.1016/j.exger.2018.12.001

Sterne, J.A. C., Savoviæ, J., Page, M. J., Elbers, R. G., Blencowe, N. S., Boutron,I., Cates, C.J., Cheng, H.Y., Corbett,M. S., Eldridge, S. M., Emberson, J. R., Hernán, M. A., Hopewell, S., Hróbjartsson, A., Junqueira, D. R., Jüni, P., Kirkham, J. J., Lasserson, T., Li, T., ... Higgins, J. P.T.(2019). RoB 2:A revised tool for assessing risk of bias in randomised trials. The BMJ, 366. https: / /doi.org/10.1136/bmj.14898

Sun, F., Norman, I. J., \& While, A. E. (2013). Physical activity in older people: A systematic review. BMC Public Health, 13(1), 449. https://doi.org/10.1186/1471-2458-13-449

Suzuki, F. S., Evangelista,A. L., Teixeira, C.V.L. S., Paunksnis, M. R. R., Rica, R. L., Evangelista, R.A. G. deT., João, G.A., Doro, M. R., Sita, D. M., Serra, A.J., Figueira Junior,A. J.,Alonso,A. C., Peterson, M., \& Bocalini, D. S. (2018). Effects of multicomponent exercise program on the functional in elderly women. Revista Brasileira de Medicina Do Esporte, 24(1), 36 $39 . \quad$ https://doi.org/10.1590/1517869220182401179669

Taglietti, M., Facci,L. M., Trelha, C. S., de Melo, F. C., da Silva, D.W., Sawczuk, G., Ruivo,T.M., de Souza,T. B., Sforza, C., \& Cardoso, J. R. (2018). Effectiveness of aquatic exercises compared to patient-education on health status in individuals with knee osteoarthritis: a randomized controlled trial. Clinical Rehabilitation, 32(6), 766-776. https://doi.org/10.1177/ 0269215517754240

Taylor,N.F., Dodd,K.J.,Shields,N., \& Bruder,A.(2007).Therapeutic exercise in physiotherapy practice is beneficial: A summary of systematic reviews 2002-2005. Australian Journal of Physiotherapy, 53(1), 7-16. https://doi.org/10.1016/S00049514(07)70057-0
Teodoro, J. L., da Silva, L. X. N., Fritsch, C. G., Baroni, B. M., Grazioli, R., Boeno, F. P., Lopez, P., Gentil, P., Bottaro, M., Pinto, R. S., Izquierdo, M., \& Cadore, E. L. (2019). Concurrent training performed with and without repetitions to failure in older men: A randomized clinical trial. Scandinavian Journal of Medicine and Science in Sports, 29(8), 1141-1152. https:// doi.org/10.1111/sms.13451

Tiggemann, C. L., Dias, C.P., Radaelli, R., Massa, J. C., Bortoluzzi, R., Schoenell, M. C.W., Noll, M.,Alberton, C. L., \& Kruel, L. F. M. (2016). Effect of traditional resistance and power training using rated perceived exertion for enhancement of muscle strength, power, and functional performance. Age, 38(2). https: / /doi.org/10.1007/s11357-016-9904-3

Tomeleri, C. M., Ribeiro, A. S., Souza, M. F., Schiavoni, D., Schoenfeld, B. J., Venturini, D., Barbosa, D. S., Landucci, K., Sardinha, L. B., \& Cyrino, E. S. (2016). Resistance training improves inflammatory level, lipid and glycemic profiles in obese older women: A randomized controlled trial. Experimental Gerontology, 84, 80-87. https://doi.org/10.1016/ j.exger.2016.09.005

Tomeleri, C. M., Souza, M. F., Burini, R. C., Cavaglieri, C. R., Ribeiro,A. S., Antunes, M., Nunes, J.P., Venturini, D., Barbosa, D. S., Sardinha, L. B., \& Cyrino, E. S. (2018). Resistance training reduces metabolic syndrome and inflammatory markers in older women: A randomized controlled trial. Journal of Diabetes, 10(4), 328-337. https://doi.org/10.1111/17530407.12614

United Nation. (2019a, June 17). World Population Prospects 2019: Highlights | Multimedia Library - United Nations Department of Economic and Social Affairs. https://www.un.org/ development/desa/publications/world-populationprospects-2019-highlights.html

United Nation. (2019b). World Population Ageing 2019 Highlights. UN. https: / / doi.org/10.18356/9df3caed-en

Valenzuela,T., Okubo,Y.,Woodbury,A., Lord, S. R., \& Delbaere, K. (2018). Adherence to Technology-Based Exercise Programs in OlderAdults: A Systematic Review. Journal of Geriatric Physical Therapy, 41(1), 49-61. https://doi.org/10.1519/ JPT.0000000000000095

Van Gelder, B. M., Tijhuis, M. A. R., Kalmijn, S., Giampaoli, S., Nissinen, A., \& Kromhout, D. (2004). Physical activity in relation to cognitive decline in elderly men: The FINE study. Neurology, 63(12), 2316-2321. https://doi.org/10.1212/ 01.WNL.0000147474.29994.35

Vargas, M. Á., \& Rosas, M.E. (2019). Impact of an aerobic physical activity program in hypertensive elderly adults. Revista Latinoamericana de Hipertension, 14(2), 142-149.

WHO.(2020).WHO Guidelines on physical activity and sedentary behaviour. In World Health Organization. https: / / apps.who.int/ iris/bitstream/handle/10665/325147/WHO-NMH-

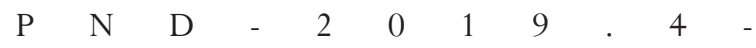
eng.pdf? sequence $=1$ \&isAllowed $=\mathrm{y} \% 0$ Ahttp: / / www.who.int/iris/handle/10665/311664\%0Ahttps: / / apps.who.int/iris/handle/10665/325147 